\title{
PENINGKATAN KESADARAN HUKUM MASYARAKAT TERHADAP UNDANG-UNDANG NOMOR 22 TAHUN 2009 SEBAGAI UPAYA MEWUJUDKAN TERCIPTANYA TERTIB LALU LINTAS DI JALAN RAYA
}

\author{
Sunaryo $^{1} *$, M. Fakih ${ }^{2}$, Ratna Syamsiar ${ }^{3}$, Kasmawati $^{4}$ \\ Bagian Hukum Keperdataan Fakultas Hukum Universitas Lampung, Bandar Lampung \\ Jl. Prof. Sumantri Brojonegoro No. 1 Bandar Lampung 35145 \\ Penulis Korespodensi : sunaryo.fhunila@gmail.com
}

\begin{abstract}
Abstrak
Permasalahan dalam kegiatan ini adalah: 1) Pada umumnya tingkat pengetahuan dan pemahaman hukum para siswa terhadap Undang Undang Nomor 22 Tahun 2009 Tentang Lalu Lintas dan Angkutan Jalan masih rendah. 2) Tingkat kedisiplinan atau kepatuhan para siswa terhadap tertib lalu lintas di jalan raya masih perlu untuk ditingkatkan, mengingat masih sering ditemukan adanya pelanggaran lalu lintas. 3) Pada umumnya para siswa belum sepenuhnya sadar akan manfaat dan pentingnya mematuhi peraturan lalu lintas untuk keselamatan di jalan. Solusi untuk mengatasi masalah tersebut adalah dengan melakukan proses edukasi dan pengenalan kaidah-kaidah hukum khususnya tentang hukum lalu lintas kepada para siswa dalam bentuk sosialisasi atau penyuluhan hukum. Kegiatan penyuluhan hukum ini cukup berhasil ditandai dengan keaktifan peserta, baik dalam mengikuti dan menyimak penyajian materi maupun dalam kesempatan tanya jawab atau diskusi. Para peserta juga ada peningkatan pengetahuan dan pemahaman tentang hukum yang mengatur mengenai ketertiban berlalu lintas. Hal ini ditunjukkan dengan hasil evaluasi dari 49,50 pada evaluasi awal menjadi 65,7 pada evaluasi akhir. Ke depan diperlukan adanya tindak lanjut serta kontinuitas dari kegiatan tersebut, baik penyuluhan hukum tentang lalu lintas maupun bidang-bidang hukum lain seperti narkoba, kenakalan remaja, atau norma-norma sosial lainnya.
\end{abstract}

Kata kunci: kesadaran hukum, lalu lintas, tertib di jalan raya

\section{Pendahuluan}

\section{A. Analisis Situasi}

Pada kehidupan masyarakat saat ini, transportasi merupakan salah satu hal yang sangat penting. Bagi individu dan masyarakat zaman sekarang, transportasi seakan sebagai bagian yang tidak terpisahkan dari kehidupan, karena manusia pada dasarnya mempunyai sifat bergerak atau mobilitas sebagai mahkluk sosial. Dengan adanya transportasi dan sarana transportasi kita dapat menuju ke berbagai tempat yang akan dituju dengan mudah. Dengan adanya transportasi tersebut,memudahkan akses bagi masyarakat untuk melakukan kegiatannya untuk pemenuhan perekonomiannya. Disamping itu transportasi juga berperan sebagai penunjang, pendorong, dan penggerak bagi pertumbuhan daerah terlebih bagi daerah yang belum berkembang, dalam upaya peningkatan dan pemerataan pembangunan serta hasil-hasilnya.
Keberadaan dan pemanfaatan sarana transportasi pada dasarnya sangat berkorelasi dan tidak bisa terlepas dari masalah lalu lintas di jalan raya. Pada realitasnya, dibalik manfaat dari keberadaan transportasi tersebut, terdapat juga berbagai permasalahan yang berkaitan dengan penggunaan jalan raya. Banyaknya pengguna jalan raya setiap hari, tidak mungkin luput dari permasalahan lalu lintas. Salah satu permasalahan dalam lalu lintas yaitu apa yang disebut kecelakaan lalu lintas. Kecelakaan bisa terjadi karena berbagai sebab, yang paling menonjol adalah karena kelalaian pengendara sendiri. Misalnya, seorang pengemudi mobil atau motor waktu mau mendahului mobil atau motor di depannya tidak memperhatikan arus lalu lintas dari arah berlawanan sehingga menabrak pengendara motor. Contoh lain misalnya pengendara mobil atau motor yang ugal-ugalan, dan lain-lain. Ini hanya merupakan sebagian permasalahan kecil yang terkait dengan kecelakaan di jalan raya namun bisa 
berakibat vatal bagi keselamatan dirinya maupun bagi orang lain.

Secara umum, dari banyak literatur, menyatakan bahwa terdapat tiga faktor yang dapat menyebabkan tingginya angka kecelakaan lalu lintas. Ketiga faktor tersebut adalah: Pertama dan yang paling banyak menjadi faktor penyebab adalah faktor pengendara atau diri kita sendiri. Banyak kasus kecelakaan akibat pengendara yang ugal-ugalan dijalan, ada juga pengendara yang mengendarai dalam kondisi mengantuk, kurang fit, dan lain sebagainya. Sebagai pengguna jalan umum. Sudah sewajibnya kita menjadi pengendara yang baik dimanapun kita berkendara. Jangan sampai mengendarai dengan ugal-ugalan atau dalam keadaan mengantuk, dan harus memakai helm SNI. Kedua, adalah faktor jalan, dibeberapa daerah masih banyak ditemukan jalan dengan kondisi rusak, berlubang, tidak rata, ataupun terlalu sempit sehingga menyebabkan jalan tersebut mempunyai resiko kecelakaan tinggi. Ketiga, adalah faktor kendaraan, misalnya kendaraan yang tidak layak jalan. Kaca spion yang tidak dipasang lengkap, padahal kaca spion mempermudah kita melihat kendaraan yang ada dibelakang. Kemudian knalpot yang diganti tidak standart akan membuat bising pengendara lainnya, dan lain-lain.

Masalah lalu lintas merupakan salah satu masalah yang berskala nasional yang berkembang seirama dengan perkembangan masyarakat. Persoalan yang dihadapi dewasa ini adalah masih tingginya angka kecelakaan lalu lintas di jalan raya. Di Indonesia, setiap tahun sekitar 9000 nyawa melayang sia-sia akibat kecelakaan lalu lintas di jalan raya. Data tersebut menunjukkan bahwa dua puluh lima orang tewas setiap hari atau ada satu orang meninggal dunia di jalan raya setiap lima puluh tujuh menit.

Hasil studi terungkap bahwa $42 \%$ dari 1260 kasus kecelakaan lalu lintas yang terjadi pada umumnya diawali dengan pelanggaran lalu lintas oleh pengemudi, sisanya sebanyak 58\% disebabkan oleh kondisi kendaraan, jalan, dan alam. Melihat itu semua diperlukan kegiatan pengendalian lalu lintas secara menyeluruh dan terpadu, tidak cukup hanya penegakan hukum semata, namun perlu melakukan upaya yang ditunjang oleh seluruh komponen bangsa, adanya peran aktif dari masyarakat dalam mewujudkan rasa kesadaran dan disiplin dalam melakukan aktivitas di jalan.

Tingginya angka kecelakaan tersebut di atas mengindikasikan bahwa tingkat kedisiplinan berlalu lintas masyarakat masih kurang. Tingkat ketaatan atau disiplin masyarakat dalam berlalu lintas yang demikian ini menunjukkan, bahwa kesadaran hukum masyarakat masih rendah. Hal ini yang kemudian menimbulkan terjadinya ketidaktertiban masyarakat di dalam berlalu lintas di jalan raya. Kondisi ini bisa jadi dikarenakan pengguna jalan raya tidak tahu ada aturan dan disiplin dalam berlalu lintas, yaitu UU Nomor 22 Tahun 2009 Tentang Lalu Lintas dan Angkutan Jalan, atau mungkin bahkan sudah menganggap tidak pentingnya aturan-aturan tersebut alih-alih dengan kepentingan yang mendesak sehingga mereka tidak lagi memikirkan keselamatan orang lain atau kepentingan umum.

Pemahaman tata tertib berlalu lintas merupakan keharusan bagi semua pengguna jalan raya, baik pengendara kendaraan mobil maupun motor. Pentingnya pemahaman terhadap tata tertib lalu lintas ini disebabkan dalam kenyataannya banyak sekali ditemukan adanya pelanggaran rambu-rambu lalu-lintas yang hampir setiap hari terjadi. Pelanggaran tersebut dilakukan tidak hanya oleh pengendara motor, tetapi sampai pengendara bis dan atau truk, bahkan oleh pengendara sampai mobil mewah. Realitas ini menunjukkan bahwa disiplin para pengendara motor dan mobil terhadap tata tertib lalu lintas masih rendah. Disiplin adalah ketaatan dan kepatuhan terhadap hukum, undangundang, peraturan, ketentuan dan norma-norma yang berlaku. Harus diyakini bahwa undangundang dan peraturan sejenisnya dibuat dengan maksud dan tujuan yang baik. Yang pasti bahwa peraturan tentang berlalu-lintas disusun untuk menjaga ketertiban dan keteraturan. Sebagai warga atau masyarakat, maka kita wajib untuk mentaati dan mematuhinya. Dengan keyakinan tadi, maka kita harus secara sadar dan ikhlas mematuhinya peraturan tersebut, bukan karena keterpaksaan. Kalau kita sudah sadar akan manfaat berdisiplin lalu-lintas, maka sebenarnya tidak perlu lagi ada polisi atau kamera pengawas di setiap jalan.

Budaya tertib lalu lintas sangatlah bermanfaat bagi kita. Rambu-rambu lalu lintas dibuat karena untuk memberitahukan sesuatu hal baik itu bersifat peringatan, larangan, perintah dan petunjuk bagi pemakai jalan. Sehingga ramburambu tersebut untuk ditaati sekaligus dapat memberikan informasi tentang kondisi jalan yang ada saat itu. Beberapa manfaat akan kita dapatkan ketika kita memiliki budaya tertib lalu lintas, antara lain: 
1. Sampai tujuan dengan selamat

Jika semua orang terutama kalangan pelajar memiliki budaya tertib lalu lintas maka keselamatanpun terjamin. Karena pelajar satu dengan yang lain saling memahami dan mengerti posisi mereka sama-sama pemakai jalan. Budaya tertib lalu lintas antara lain menjadi pengguna jalan yang baik, menaati rambu-rambu lalu lintas, serta peraturan yang mengenai lalu lintas. Sehingga mereka sampai tujuan dengan selamat.

2. Mengurangi tingkat kecelakaan pada kalangan pelajar

Menurut data catatan PT Jasa Raharja Cabang Jatim terungkap 70 persen dari total 4.286 korban kecelakaan sepanjang Januari hingga Maret 2014 adalah usia produktif. Kebanyakan dari kalangan pelajar, mahasiswa, dan pegawai swasta. Sehingga dengan adanya kesadaran dalam memiliki budaya tertib lalu lintas maka dapat mengurangi tingkat kecelakaan pada kalangan pelajar.

3. Mengurangi tingkat pelanggaran lalu lintas Dengan adanya budaya lalu lintas di jalan pada kalangan pelajar, maka tingkat pelanggaran lalu lintaspun akan berkurang. Sehingga kedamaian pemakai jalan akan lebih meningkat. Contohnya memakai mesin knalpot yang berstandart nasional makan pemakai jalan yang lain tidak akan terganggu dengan suara knalpot yang tidak berstandart nasional.

Melihat pada manfaat dari tertib lalu lintas di atas, maka sudah selayaknya setiap anggota masyarakat untuk selalu menjaga dan mematuhinya dengan sungguh-sungguh. Jika dalam realitasnya masih banyak terjadinya pelanggaran-pelanggaran yang berakibat pada kecelakaan, maka saat ini harus lebih ditingkatkan lagi kedasaran masyarakat akan pentingnya budaya tertib lalu lintas. Menumbuhkan budaya tertib lalu lintas di jalan raya pada masyarakat dan kalangan pelajar harus ditingkatkan dan dimulai dari sekarang. Hal ini dikarenakan tingkat kesadaran dan sikap masyarakat (termasuk di dalamnya pelajar) terhadap etika dan budaya tertib lalu lintas di jalan ditengarai semakin menurun. Kebanyakan dari mereka tidak lagi mempedulikan rambu-rambu lalu lintas yang ada di jalan. Bahkan, sebagian para pelajar tidak pernah merasa jera dengan apa yang mereka lalukan, meskipun hal itu telah melanggar lalu lintas. Lebih ironisnya lagi, mereka seolaholah bangga dan merasa dirinya hebat jika ia bisa menunjukkan kepada teman-temannya bahwa ia berani melakukan tindakan yang bertentangan dengan disiplin dan aturan lalu lintas di jalan raya.

Menyikapi fenomena dan realitas di atas dan dalam rangka untuk meningkatkan pemahaman dan kesadaran hukum masyarakat, khususnya bagi para pelajar terhadap tertib lalu lintas di jalan raya, maka dirasakan urgensinya untuk diadakan penyuluhan hukum dengan judul: "Peningkatan Kesadaran Hukum Masyarakat Terhadap UndangUndang Nomor 22 Tahun 2009 Sebagai Upaya Mewujudkan Terciptanya Tertib Lalu Lintas di Jalan Raya".

\section{B. Identifikasi dan Perumusan Masalah}

Berdasarkan analisis situasi dan hasil survai pendahuluan di lapangan, maka dapat diidentifikasi beberapa masalah, yaitu:

1. Pada umumnya tingkat pengetahuan dan pemahaman hukum para pelajar/siswa terhadap UU Nomor 22 Tahun 2009 Tentang Lalu Lintas dan Angkutan Jalan masih rendah.

2. Tingkat kedisiplinan atau kepatuhan para pelajar/siswa terhadap tertib lalu lintas di jalan raya masih perlu untuk ditingkatkan, mengingat masih seringnya ditemukan adanya pelanggaran lalu lintas.

3. Pada umumnya para pelajar/siswa belum sepenuhnya sadar akan manfaat dan pentingnya mematuhi peraturan lalu lintas untuk keselamatan di jalan, baik bagi dirinya sendiri maupun bagi pengguna jalan lain.

Mengacu pada identifikasi masalah di atas, maka perumusan masalah yang relevan dalam kegiatan ini adalah: Bagaimana upaya yang dilakukan untuk meningkatkan kesadaran hukum pelajar/siswa terhadap UU Nomor 22 Tahun 2009 sehingga tercipta budaya tertib lalu lintas di jalan raya?

\section{Tujuan Kegiatan}

Secara umum tujuan dari kegiatan penyuluhan hukum ini adalah untuk meningkatkan kesadaran hukum masyarakat, khususnya bagi para pelajar/siswa SMK Patria Gadingrejo terhadap UU Nomor 22 Tahun 2009, sehingga akan tercipta budaya tertib lalu lintas di jalan raya. Sedangkan secara lebih khusus, kegiatan ini bertujuan untuk:

1. Meningkatkan pengetahuan dan pemahaman masyarakat khususnya para pelajar/siswa SMK Patria Gadingrejo terhadap peraturan lalu lintas. 
2. Setelah memperoleh pengetahuan dan pemahaman diharapkan masyarakat (dalam hal ini pelajar/siswa SMK Patria Gadingrejo) selanjutnya akan memiliki kesadaran hukum yang tinggi sehingga ada perubahan pola sikap yang menunjukkan ketaatannya pada peraturan sehingga akan terwujud suasana tertib lalu lintas.

3. Meminimalisir terjadinya pelanggaran lalu lintas dan semakin berkurangnya tingkat kecelakaan lalu lintas di jalan raya.

\section{Manfaat Kegiatan}

Kegiatan pengabdian kepada masyarakat dalam bentuk penyuluhan hukum ini diharapkan akan dapat memberikan beberapa manfaat, antara lain: 1) Pengetahuan dan pemahaman para pelajar/siswa SMK Patria Gadingrejo terhadap peraturan lalu lintas akan meningkat; 2) Menumbuhkan dan mendorong para pelajar/siswa SMK Patria Gadingrejo untuk berperilaku disiplin atau tertib lalu lintas di jalan raya; 3) Diharapkan dapat menekan terjadinya pelanggaran dan kecelakaan lalu lintas di jalan raya yang bisa membahayakan dan merugikan baik bagi dirinya sendiri maupun bagi penggunang jalan lain.

\section{Bahan dan Metode}

\section{A. Kesadaran Hukum Masyarakat}

Pada hakikatnya semua aturan dan ketentuan yang ada di masyarakat merupakan suatu kaidah atau norma sebagai pedoman bagi manusia di dalam melakukan hubungannya dengan orang lain agar tercipta suasana tertib dan teratur. Dalam hal ini Soleman B.Taneko menyatakan bahwa hukum mempunyai fungsi sebagai pedoman kepada warga masyarakat bagaimana mereka harus bertingkah laku atau bersikap dalam menghadapi masalahmasalah yang terutama menyangkut kebutuhan pokok. Kondisi masyarakat yang tertib dan teratur sebagaimana diharapkan di atas tentu hanya akan terwujud manakala setiap orang dalam masyarakat melaksanakan isi ketentuan dari kaidah atau norma tersebut di dalam setiap aktivitasnya. Sudikno Mertokusumo menegaskan, bahwa kaidah hukum bukanlah sekedar pedoman yang beku saja, tetapi harus ditaati atau dipatuhi.

Kandungan suatu aturan atau hukum sebagai kaidah pada dasarnya merupakan suatu pesan. Pesan tersebut tertuju baik kepada warga masyarakat secara umum, maupun pembuat hukum itu sendiri. Oleh karena itu, hukum harus disampaikan kepada suatu khalayak (audience) tertentu. Apabila hukum tidak disampaikan secara aktif dan kontinyu kemungkinan kecil hukum tersebut mempunyai efek terhadap perilaku manusia, baik secara pribadi maupun di dalam kehidupan berkelompok.

Oleh karena itu, menurut Soetandyo Wignjosoebroto adanya slogan yang dikenal dalam ilmu hukum "semua orang dianggap tahu hukum/undang-undang" merupakan suatu pernyataan yang tidak akan mampu membantu peningkatan pemahaman hukum atau kesadaran hukum masyarakat. Menghadapi persoalan demikian, maka perlu dikembangkan usaha penyebarluasan informasi mengenai hukum, mengenai isi normatif suatu hukum, juga mengenai ide-ide pembenarnya. Penyebarluasan informasi mengenai hukum dalam bentuk sosialisasi atau penyuluhan hukum kepada masyarakat dengan demikian sangat penting dalam rangka terwujudnya efektivitas penegakan hukum di masyarakat.

Proses komunikasi bukanlah tindakan yang bersifat insidental tetapi merupakan kegiatan yang berkesinambungan. Friedmaan mengemukakan pentingnya komunikasi hukum "a legal act (rule, doctrins, practice) whatever functions it serves, is message". Komunikasi dalam arti sebenarnya merupakan suatu penyampaian dan penerimaan lambang-lambang yang mengandung arti-arti tertentu. Berbeda dengan komunikasi pada taraf pengkabaran saja, yang tidak ada pola edukatif secara intensif kepada warga masyarakat. Oleh karena itu produk undang-undang yang dikeluarkan oleh negara kalau sampai pada taraf pengkabaran saja sulit memperoleh hasilnya yang maksimum maupun optimum.

Tujuan komunikasi mencakup tiga komponen, yaitu kognitif, afektif, dan konatif. Ketiga komponen tersebut menurut Soerjono Soekanto berkaiatan dengan komunikasi hukum. Dengan demikian usaha komunikasi tidak lain adalah untuk membangkitkan compliance (ketulusan atau kerelaan dalam mentaati hukum) dan perlu diawali dengan penyebarluasan isi hukum yang tengah berlaku. Berdasarkan pada kerangka pemikiran di atas, maka dalam bidang hukum lalu lintas perlu adanya komunikasi. Sebagai proses komunikasi hukum yang dilakukan adalah melalui sosialisasi peraturan tentang lalu lintas kepada masyarakat.

Kesadaran hukum merupakan salah satu ciri bahwa masyarakat telah memahami dan mengerti 
hukum. Kesadaran hukum warga negara dapat terlihat dari perilaku di mana dia berada. Kesadaran hukum adalah kesadaran yang ada pada setiap manusia tentang apa hukum itu atau apa seharusnya hukum itu, suatu kategori tertentu dari hidup kejiwaan kita dengan mana kita membedakan antara hukum dan tidak hukum (onrecht), antara yang seyogyanya dilakukan dan tidak seyogyanya dilakukan.

Kesadaran hukum mempunyai beberapa konsepsi, salah satunya konsepsi mengenai kebudayaan hukum. Konsepsi ini mengandung ajaran-ajaran kesadaran hukum lebih banyak mempermasalahkan kesadaran hukum yang dianggap sebagai mediator antara hukum dengan perilaku manusia, baik secara individual maupun kolektif. Menurut Soerjono Soekanto, kesadaran hukum sebenarnya merupakan kesadaran atau nilai-nilai yang terdapat di dalam diri manusia tentang hukum yang ada atau tentang hukum yang diharapkan ada. Sebenarnya yang ditekankan adalah nilai-nilai tentang fungsi hukum dan bukan suatu penilaian hukum terhadap kejadian-kejadian yang konkrit dalam masyarakat yang bersangkutan. Oleh karena itu untuk meningkatkan kesadaran hukum menurut Sudikno ada dua cara yaitu: (1) dengan memperberat ancaman hukuman/ mengetatkan pengawasan (melalui tindakan drastis), (2) dengan cara menanamkan nilai-nilai hukum kepada masyarakat (melalui tindakan pendidikan).

Lebih lanjut Soerjono Soekanto menyatakan bahwa indikator-indikator dari kesadaran hukum sebenarnya merupakan petunjuk yang relatif kongkrit tentang taraf kesadaran hukum. Dijelaskan lagi secara singkat bahwa :

1. Indikator pertama adalah pengetahuan hukum. Seseorang mengetahui bahwa perilaku-perilaku tertentu itu telah diatur oleh hukum. Peraturan hukum yang dimaksud disini adalah hukum tertulis maupun hukum yang tidak tertulis. Perilaku tersebut menyangkut perilaku yang dilarang oleh hukum maupun perilaku yang diperbolehkan oleh hukum.

2. Indikator kedua adalah pemahaman hukum. Seseorang warga masyarakat mempunyai pengetahuan dan pemahaman mengenai aturanaturan tertentu, misalnya adanya pengetahuan dan pemahaman yang benar dari masyarakat tentang hakikat dan arti pentingnya UU No. 1 Tahun 1974 tentang perkawinan.
3. Indikator yang ketiga adalah sikap hukum . Seseorang mempunyai kecenderungan untuk mengadakan penilaian tertentu terhadap hukum.

4. Indikator yang keempat adalah perilaku hukum, yaitu dimana seseorang atau dalam suatu masyarakat warganya mematuhi peraturan yang berlaku.

Berdasarkan keempat indikator tersebut di atas, menunjukkan tingkatan-tingkatan pada kesadaran hukum tertentu di dalam perwujudannya. Apabila seseorang mengetahui hukum. maka bisa dikatakan bahwa tingkat kesadaran hukumnya masih rendah. Akan tetapi, kalau seseorang atau suatu masyarakat telah berperilaku sesuai hukum, maka tingkat kesadaran hukumnya telah tinggi.

\section{B. Tertib dalam Lalu lintas}

Lalu Lintas dan Angkutan Jalan sebagai bagian dari sistem transportasi nasional harus dikembangkan potensi dan perannya untuk mewujudkan keamanan, keselamatan, ketertiban, dan kelancaran berlalu lintas dan angkutan jalan dalam rangka mendukung pembangunan ekonomi dan pengembangan wilayah. Atas pertimbangan itu, maka diundangkan UU Nomor 22 Tahun 2009 Tentang Lalu Lintas dan Angkutan Jalan. Tertib Lalu Lintas mempunyai tujuan untuk mewujudkan lalu lintas dan angkutan jalan yang selamat, aman, cepat, lancar, tertib dan teratur, nyaman dan efisien melalui manajemen lalu lintas dan rekayasa lalu lintas. Tata cara berlalu lintas di jalan diatur dengan peraturan perundangan menyangkut arah lalu lintas, prioritas menggunakan jalan, lajur lalu lintas, jalur lalu lintas dan pengendalian arus di persimpangan.

Pengertian lalu lintas di dalam Undangundang No 22 Tahun 2009 didefinisikan sebagai gerak kendaraan dan orang di ruang lalu lintas jalan, sedang yang dimaksud dengan ruang lalu lintas jalan adalah prasarana yang diperuntukkan bagi gerak pindah kendaraan, orang, dan/atau barang yang berupa Jalan dan fasilitas pendukung. Menurut Djajoesman yang dimaksud secara harfia dengan lalu lintas, diartikan sebagai gerak (bolak balik) manusia atau barang dari satu tempat ke tempat lainnya dengan menggunakan sarana jalan umum. Alat gerak yang dapat digunakan untuk berpindah dari satu tempat ke tempat yang lain itu sering disebut sebagai kendaraan yang terbagi menjadi dua jenis yaitu kendaraan bermotor dan kendaraan tidak bermotor. Kendaraan bermotor yaitu kendaraan yang menggunkan mesin untuk 
bisa berjalan. Contohnya sepeda motor, mobil, dan lain-lain. Sedangkan kendaraan tidak bermotor yaitu kendaraan yang tidak menggunakan mesin melainkan menggunakan tenaga manusia atau hewan. Misalnya andong, becak, dan lain-lain.

Ada tiga komponen terjadinya lalu lintas yaitu manusia sebagai pengguna, kendaraan, dan jalan. Ketiga komponen tersebut saling berkaitan, di mana dalam pergerakan kendaraan yang memenuhi persyaratan kelaikan dikemudikan oleh pengemudi mengikuti aturan lalu lintas yang ditetapkan berdasarkan peraturan perundangan yang menyangkut lalu lintas dan angkutan jalan melalui jalan yang memenuhi persyaratan sebagai berikut:

1. Manusia sebagai pengguna, dapat berperan sebagai pengemudi atau pejalan kaki yang dalam keadaan normal mempunyai kemampuan dan kesiagaan yang berbeda-beda (waktu reaksi, konsentrasi). Perbedaan-perbedaan tersebut masih dipengaruhi oleh keadaan fisik dan psikologi, umur serta jenis kelamin dan pengaruh-pengaruh luar seperti cuaca, penerangan/lampu jalan dan tata ruang.

2. Kendaraan, digunakan oleh pengemudi mempunyai karakteristik yang berkaitan dengan kecepatan, percepatan, perlambatan, dimensi dan muatan yang membutuhkan ruang yang cukup untuk bisa bermanuver dalam lalu lintas.

3. Jalan, merupakan lintasan yang direncanakan untuk dilalui kendaraan bermotor maupun kendaraan tidak bermotor termasuk pejalan kaki. Jalan tersebut direncanakan untuk mampu mengalirkan aliran lalu lintas dengan lancar dan mampu mendukung beban muatan sumbu kendaraan serta aman, sehingga dapat meredam angka kecelakaan lalu-lintas.

Selain dari tiga komponen di atas, untuk menunjang ketertiban berlalu lintas di jalan raya para pengguna jalan juga difasilitasi dengan beragam rambu-rambu lalu lintas. Keberadaan rambu-rambu lalu lintas ini sangatlah bermanfaat bagi pengguna jalan. Rambu-rambu lalu lintas dibuat karena untuk memberitahukan sesuatu hal baik itu bersifat peringatan, larangan, perintah dan petunjuk bagi pemakai jalan. Sehingga ramburambu tersebut untuk ditaati sekaligus dapat memberikan informasi tentang kondisi jalan yang ada saat itu. Beberapa manfaat akan kita dapatkan ketika kita memiliki budaya tertib lalu lintas, antara lain:

1. Sampai tujuan dengan selamat
Jika semua orang terutama kalangan pelajar memiliki budaya tertib lalu lintas maka keselamatanpun terjamin. Karena pelajar satu dengan yang lain saling memahami dan mengerti posisi mereka sama-sama pemakai jalan. Budaya tertib lalu lintas antara lain menjadi pengguna jalan yang baik, menaati rambu-rambu lalu lintas, serta peraturan yang mengenai lalu lintas. Sehingga mereka sampai tujuan dengan selamat.

2. Mengurangi tingkat kecelakaan pada kalangan pelajar

Menurut data catatan PT Jasa Raharja Cabang Jatim terungkap 70 persen dari total 4.286 korban kecelakaan sepanjang Januari hingga Maret 2014 adalah usia produktif. Kebanyakan dari kalangan pelajar, mahasiswa, dan pegawai swasta. Sehingga dengan adanya kesadaran dalam memiliki budaya tertib lalu lintas maka dapat mengurangi tingkat kecelakaan pada kalangan pelajar.

3. Mengurangi tingkat pelanggaran lalu lintas

Dengan adanya budaya lalu lintas di jalan pada kalangan pelajar, maka tingkat pelanggaran lalu lintaspun akan berkurang. Sehingga kedamaian pemakai jalan akan lebih meningkat. Contohnya memakai mesin knalpot yang berstandart nasional makan pemakai jalan yang lain tidak akan terganggu dengan suara knalpot yang tidak berstandar nasional.

\section{Pelanggaran dan Sanksi dalam Lalu Lintas}

Aturan dibuat untuk ditaati, bukan untuk dilanggar, begitu juga dengan dikeluarkannya UU Nomor 22 Tahun 2009. Disebut ada pelanggaran berlalu lintas apabila seseorang itu tidak mematuhi ketentuan-ketentuan dalam berlalu lintas sebagaimana yang telah ditetapkan. Keberadaan ketentuan-ketentuan dalam berlalu lintas diciptakan untuk mengatur pengguna jalan agar tercipta keteraturan dalam berlalu lintas serta mengurangi tingginya angka kecelakaan. Ada korelasi antara pelanggaran lalu lintas dengan tingkat kecelakaan. Semakin tinggi angka pelanggaran, maka akan tinggi pula angka kecelakaan. Pelanggaran dalam berlalu lintas dapat berakibat fatal diantaranya tingginya angka kecelakaan yang menimbulkan kerugian yang tidak kecil. Berdasarkan fakta kecelakaan yang terjadi kebanyakan bisebabkan akibat pelanggaran dalam berlalu lintas.

Secara rinci, kecelakaan yang terjadi dalam lalu lintas disebabkan oleh 4 (empat) faktor, yaitu: 
1. Faktor Human/Pengemudi (manusia), yaitu:

a. Tidak disiplin (melanggar peraturan/ramburambu lalu lintas), misalnya: melanggar lampu traffic light dan marka, parkir sembarangan, rem mendadak, ngebut, dsb.

b. Emosional/tidak sabaran, mungkin karena tergesa-gesa 'kejar tayang' atau ada hal yang sangat penting/mendadak, dsb.

c. Daya konsentrasi berkurang, hal ini disebabkan karena mengemudi sambil bicara, menelepon/sms, melamun, berkhayal, dsb.

d. Kurang trampil dalam mengemudi (baru belajar, jam terbang minim).

e. Mengantuk/lelah (pulang kerja, perjalanan jauh, habis sakit, dsb).

f. Mabuk (dalam pengaruh obat/minuman)

g. Kesehatan (kondisi tubuh yang kurang fit).

2. Faktor Kendaraan, seperti: Kendaraan tidak laik jalan (usia tua, rusak); Ban tiba-tiba pecah (bersifat insidentil); Rem blong, lampu tidak berfungsi/tidak ada; Melebihi muatan; Bukan peruntukannya (ban dan bodi modif).

3. Faktor Jalan, misalnya: Jalan sempit; Jalan licin (habis hujan, banjir, ada ceceran minyak/oli,dsb); Jalan bergelombang; Tikungan tajam, tanjakan/menurun; Jalan terlalu mulus/hotmix yang bikin pengendara merasa sangat nyaman akhirnya malah jadi lengah.

4. Faktor Cuaca, contohnya: Berkabut; Hujan; Longsor; Banjir.

Dari keempat faktor di atas faktor manusia merupakan faktor utama terjadinya berbagai kecelakaan dalam lalu lintas. Berdasarkan data tahun 2011 urutan faktor penyebab terjadinya kecelakaan dalam lalu lintas (dalam prosentase) adalah sebagai berikut: (1) Faktor manusia (80\%90\%), (2) Faktor jalan dan lingkungan (10\%-20\%), (3) Faktor kendaraan (5\%-10\%), dan (4) Faktor cuaca $(1 \%-5 \%)$. Berdasarkan data-data tersebut, cara yang dapat dilakukan untuk mengurangi tingginya angka kecelakaan, antara lain dengan cara penegakan hukum di jalan, yaitu dengan cara mengadakan operasi SIM, perlengkapan kendaraan dan helm. Penegakan hukum harus tegas untuk mambuat pelanggar jera tetapi harus dilakukan sesuai Undang-Undang No. 22 Tahun 2009.

Berikut ini beberapa contoh aturan yang tertera pada Undang-Undang No. 22 Tahun 2009, yang dapat dijadikan acuan di dalam penegakan hukum, yaitu:
1. Pasal 106 Ayat (8) "setiap orang yang mengemudikan ranmor dan penumpang sepeda motor wajib mengenakan helm yang mengenakan hekm yang berstandar nasional"

2. Pasal 107 Ayat (2) "sepeda motor wajib menyalakan lampu utama pada siang hari"

3. Pasal 106 Ayat (4) "setiap orang yang mengemudi kendaraan bermotor dijalan wajib memenuhi ketentuan rambu perintah atau rambu larangan; marka jalan, aalt pemberi isyarat lalin, gerakan lalin, berhenti dan parkir, peringatan dengan bunyi dan sinar, kecepatan, tata cara penggandengan"

4. Pasl 285 Ayat (1) "mengemudikan sepeda motor wajib memenuhi persyaratan teknis dan laik jalan yang meliputi kaca spion, klakson, lampu utama, lampu rem, lampu penunjuk arah, alat pemantul cahaya, alat pengukur kecepatan, knalpot, dan kedalaman alur ban"

5. Pasal 77 Ayat (1) Jo Pasal 281 "setiap orang mengemudi kendaraan bermotor dijalan wajib memiliki SIM sesuai jennies kendaraan bermotor yang dikemudikan", dsb.

Terhadap beberapa contoh ketentuan yang dapat dijadikan acuan dalam penegakan hukum di atas, maka UU No. 22 Tahun 2019 juga mengatur sanksi jika ada pelanggaran, antara lain yaitu:

Pasal 281: Setiap orang yang mengemudikan Kendaraan Bermotor di Jalan yang tidak memiliki Surat Izin Mengemudi sebagaimana dimaksud dalam Pasal 77 ayat (1) dipidana dengan pidana kurungan paling lama 4 (empat) bulan atau denda paling banyak Rp 1.000.000,00 (satu juta rupiah).

Pasal 285 (1): Setiap orang yang mengemudikan Sepeda Motor di Jalan yang tidak memenuhi persyaratan teknis dan laik jalan yang meliputi kaca spion, klakson, lampu utama, lampu rem, lampu penunjuk arah, alat pemantul cahaya, alat pengukur kecepatan, knalpot, dan kedalaman alur ban sebagaimana dimaksud dalam Pasal 106 ayat (3) juncto Pasal 48 ayat (2) dan ayat (3) dipidana dengan pidana kurungan paling lama 1 (satu) bulan atau denda paling banyak Rp 250.000,00 (dua ratus lima puluh ribu rupiah).

\section{Kerangka Pemecahan Masalah dan Realisasinya \\ A. Kerangka Pemecahan Masalah}

Sebagaimana dipaparkan sebelumnya bahwa pada umumnya tingkat pengetahuan dan pemahaman masyarakat, khususnya pada pelajar/siswa SMK Patria Gadingrejo terhadap 
peraturan lalu lintas masih rendah. Oleh karena itu, solusi untuk mengatasi masalah tersebut di atas, diperlukan adanya proses pengajaran dan pendidikan kaidah-kaidah hukum khususnya tentang hukum lalu lintas dalam bentuk sosialisasi atau penyuluhan hukum. Melalui kegiatan penyuluhan ini, diharapkan cukup efektif dalam mentransformasi pengetahuan mengenai ketentuan hukum atau peraturan lalu lintas yang berlaku.

Transformasi yang diberikan kepada masyarakat (pelajar/siswa SMK Patria Gadingrejo) berupa pengetahuan hukum lalu lintas meliputi disiplin atau tertib lalu lintas, pelanggaran lalu lintas, dan berbagai sanksi atas pelanggaran yang diatur di dalam UU Nomor 22 Tahun 2009. Dengan transformasikannya materi-materi tersebut, mereka akan menerima pengetahuan baru dan mencapai pola sikap baru. Perubahan perilaku khalayak sasaran yang memperoleh penyuluhan hukum dapat digambarkan sebagai berikut:

Tabel 1. Kerangka pemecahan masalah

\begin{tabular}{|c|c|c|c|}
\hline No & Kondisi Awal & Perlakuan & $\begin{array}{c}\text { Luaran yang } \\
\text { Dihasilkan }\end{array}$ \\
\hline \multirow[t]{9}{*}{1} & Siswa SMK & Ceramah & Siswa SMK \\
\hline & Patria belum & dan diskusi & Patria dapat \\
\hline & $\begin{array}{l}\text { mengetahui } \\
\text { dan }\end{array}$ & & $\begin{array}{l}\text { mengetahui } \\
\text { dan }\end{array}$ \\
\hline & memahami & & memahami \\
\hline & tentang & & tentang \\
\hline & pengertian & & pengertian \\
\hline & disiplin atau & & disiplin atau \\
\hline & tertib lalu & & tertib lalu \\
\hline & lintas & & lintas \\
\hline \multirow[t]{9}{*}{2} & Siswa SMK & Ceramah & Siswa SMK \\
\hline & Patria belum & dan diskusi & Patria dapat \\
\hline & $\begin{array}{l}\text { mengetahui } \\
\text { dan }\end{array}$ & & $\begin{array}{l}\text { mengetahui } \\
\text { dan }\end{array}$ \\
\hline & memahami & & memahami \\
\hline & tentang arti & & arti penting \\
\hline & penting dan & & dan manfaat \\
\hline & manfaat dari & & dari tertib \\
\hline & tertib lalu & & lalu lintas \\
\hline & lintas & & \\
\hline \multirow[t]{6}{*}{3} & Siswa SMK & Ceramah & Siswa SMK \\
\hline & Patria belum & dan diskusi & Patria dapat \\
\hline & $\begin{array}{l}\text { mengetahui } \\
\text { dan }\end{array}$ & & $\begin{array}{l}\text { mengetahui } \\
\text { dan }\end{array}$ \\
\hline & memahami & & memahami \\
\hline & $\begin{array}{l}\text { tentang jenis- } \\
\text { jenis }\end{array}$ & & $\begin{array}{l}\text { tentang jenis- } \\
\text { jenis }\end{array}$ \\
\hline & pelanggaran & & pelanggaran \\
\hline
\end{tabular}

\begin{tabular}{lcl}
\multicolumn{1}{c}{$\begin{array}{l}\text { lalu lintas } \\
\text { beserta } \\
\text { akibatnya }\end{array}$} & $\begin{array}{l}\text { lalu lintas } \\
\text { beserta } \\
\text { akibatnya }\end{array}$ \\
Siswa SMK & Ceramah & Siswa SMK \\
Patria belum & dan diskusi & $\begin{array}{l}\text { Patria dapat } \\
\text { mengetahui } \\
\text { dan }\end{array}$ \\
memahami & mengetahui \\
tentang & memahami \\
berbagai & tentang \\
sanksi atas & berbagai \\
pelanggaran & sanksi atas \\
lalu lintas & pelanggaran \\
& lalu lintas \\
\hline
\end{tabular}

\section{B. Realisasi Pemecahan Masalah}

Berdasarkan data dan informasi yang diperoleh, dapat diketahui bahwa masyarakat pelajar/siswa SMK Patria Gading Rejo yang menjadi khalayak sasaran dalam kegiatan ini masih memiliki pengetahuan yang rendah tentang materi penyuluhan. Hal-hal yang terkait khususnya dengan kewajiban-kewajiban yang mesti dilakukan untuk terciptanya ketertiban di jalan raya belum dimengerti dengan baik oleh para pelajar siswa SMK Patria Gading Rejo. Oleh karena itu, untuk mengatasi permasalahan tersebut, siswa SMK Patria Gading Rejo perlu ditingkatkan pemahamannya melalui suatu kegiatan sosialisasi hukum berupa penyuluhan hukum yang berhubungan dengan ketertiban berlalu lintas dalam rangka untuk meminimalisir terjadinya kecelakaan di jalan raya.

\section{Hasil dan Pembahasan}

\section{A. Evaluasi Terhadap Khalayak Sasaran}

Untuk mengetahui tingkat keberhasilan atau kegagalan sosialisasi ini, maka kepada khalayak sasaran perlu dilakukan evaluasi kegiatan. Evaluasi dilakukan secara spesifik untuk mengetahui tingkat pengetahuan dan pemahamannya terhadap materi yang disampaikan. Adapun langkah-langkah evalusinya meliputi:

1. Evaluasi awal

Evaluasi awal dilakukan sebelum penyampaian materi, dengan maksud untuk mengetahui tingkat pengetahuan dan pemahaman tentang pengertian disiplin atau tertib lalu lintas, manfaat tertib lalu lintas, serta jenis-jenis pelanggaran beserta sanksinya. Evaluasi ini dilakukan dengan menggunakan beberapa daftar pertanyaan mengenai aspek pengetahuan dan pemahaman khalayak sasaran terhadap 
materi hukum di atas. Perkembangan nilai antara evaluasi awal dengan evaluasi akhir tercantum dalam tabel terlampir. Adapun hasil rata-rata evaluasi awal dari 50 orang peserta baru mencapai 49,50. Hal ini menunjukkan tingkat pengetahuan dan pemahaman peserta kegiatan tergolong rendah.

2. Evaluasi proses.

Evaluasi proses dilakukan selama proses kegiatan sosialisasi hukum berlangsung. Evaluasi ini dilakukan dengan cara menilai partisipasi aktif peserta melalui sejumlah pertanyaan dan bobot pertanyaan yang diajukan. Peserta yang hadir ternyata memberikan sikap yang positif terhadap kegiatan ini. Selain itu, peserta selalu mengukapkan kasus-kasus yang terjadi mengenai berbagai jenis pelanggaran lalu lintas beserta dengan sanksi-sanksinya, baik sanksi pidana kurungan atau pun besaran sanksi denda.

3. Evaluasi akhir

Evaluasi akhir digunakan dengan menggunakan daftar pertanyaan yang sama pada waktu pra-uji yang diselenggarakan pada akhir kegiatan. Evaluasi akhir bertujuan untuk mengetahui keberhasilan kegiatan sosialisasi dengan membandingkan pengetahuan dan pemahaman sebelum dan sesudah kegiatan dilakukan. Hasil yang dicapai para peserta ditunjukkan dengan melihat perkembangan hasil evaluasi akhir (En) dikurangi hasil evaluasi awal (Ea) atau $\mathrm{K}=(\mathrm{En})$ - (Ea). Jika terjadi perubahan terhadap pengetahuan dan pemahaman hukum, yaitu dari tidak tahu menjadi tahu, dari tidak /kurang faham menjadi faham, maka sosialisasi ini dapat dikatakan berhasil. Tingkat perubahan kedua hal tersebut di atas dapat dilihat dari selisih antara hasil pra-uji dan hasil pasca-uji yang meliputi tingkat perubahan pemahaman. Jika hasil prauji lebih rendah, nilainya daripada setelah dilakukan kegiatan sosialisasi, atau hasil pascauji nilainya lebih tinggi daripada pra-uji, maka tingkat pencapaian pengetahuan khalayak sasaran kegiatan dapat dikatakan berhasil. Berdasarkan hasil evaluasi awal dan akhir maka diperoleh angka peningkatan, yaitu dari 49,50 (evaluasi awal) menjadi 65,70 (evaluasi akhir). Dengan demikian, di sini telah terjadi peningkatan tingkat pengetahuan dan pemahaman tentang materi yang disajikan.
Peningkatan pengetahuan dan pemahaman masyarakat meliputi hal-hal tentang pengertian disiplin atau tertib lalu lintas, manfaat tertib lalu lintas, serta jenis-jenis pelanggaran beserta sanksinya.

\section{B. Faktor Pendukung dan Faktor Penghambat}

Keberhasilan dari kegiatan penyuluhan ini terutama didukung oleh :

a. Antusias khalayak sasaran yang benar-benar menginginkan adanya informasi tentang hukum yang mengatur mengenai lalu lintas dan angkutan jalan raya.

b. Adanya dukungan dari instansi di mana sosialisasi atau penyuluhan ini dilakukan, baik oleh Kepala SMK Patria Gading Rejo maupun jajarananya para dewan guru setempat.

Mengingat adanya faktor pendukung di atas, maka dalam pelaksanaan kegiatan ini pada dasarnya tidak menghadapi hambatan atau kesulitan yang mendasar.

\section{Penutup}

\section{A. Kesimpulan}

Berdasarkan pelaksanaan dan evaluasi yang telah dilaksanakan dari kegiatan penyuluhan ini, maka dapat disimpulkan sebagai berikut:

a. Kegiatan penyuluhan hukum ini cukup berhasil, yang ditandai dengan keaktifan peserta, baik dalam mengikuti dan menyimak penyajian materi maupun dalam kesempatan tanya jawab atau diskusi.

b. Adanya peningkatan pengetahuan dan pemahaman tentang hukum yang mengatur mengenai ketertiban berlalu lintas. Hal ini ditunjukan dengan hasil evaluasi dari 49,50 (evaluasi awal) menjadi 65,70 (evaluasi akhir). Peningkatan pengetahuan dan pemahaman peserta meliputi pengertian disiplin atau tertib lalu lintas, manfaat tertib lalu lintas, serta jenisjenis pelanggaran beserta sanksinya. Diharapkan dengan meningkatnya pengetahuan dan pemahaman masyarakat tentang peraturan lalu lintas akan meningkat pula kesadaran hukumnya. Keberhasilan dari kegiatan penyuluhan ini tidak terlepas dari dukungan dan antusias para siwa SMK Patria Gading Rejo sebagai khalayak sasara serta adanya dukungan dari Kepala Sekolah dan dewan guru setempat. 


\section{B. Saran}

Dengan adanya sambutan yang positif dari khalayak sasaran setempat terhadap kegiatan penyuluhan ini, maka perlu adanya tindak lanjut serta kontinuitas dari kegiatan tersebut. Ke depan, materi yang perlu disampaikan pada masyarakat bisa jadi bukan hanya kaidah/aturan-aturan hukum yang mengatur tentang lalu lintas saja, tetapi di bidang lain seperti narkoba, kenakalan remaja, atau norma-norma sosial lainnya. Hal ini disebabkan ditengarai masih banyaknya di kalangan masyarakat dan siswa yang belum mengetahui dan memahami secara detail dan komprehensif berbagai ketentuan hukum di atas. Oleh karena itu, penyampaian informasi tentang hukum melalui penyuluhan-penyuluhan kepada masyarakat dan siswa masih sangat diperlukan.

Terimakasih kepada Fakultas Ekonomi Universitas Negeri Semarang (UNNES) yang telah memberikan dukungan dana sehingga kegiatan pengabdian masyarakat berjalan dengan lancar.

\section{Daftar Pustaka}

Friedman, Lawrence M. 1977. Law and Society: An Introduction, Englewood Cliffs. Prentice Hall, Inc, New Jersey.

H.S., Djajoesman. 1976. Grafik Lalu Lintas dan Angkutan Jalan, Balai Pustaka, Jakarta.

Jurnal Pengabdian kepada Masyarakat Sakai Sambayan, Vol. 2 No 1 Maret 2018.

Kansil, C.S.T., dkk. 1995. Disiplin Berlalu Lintas di Jalan Raya, P.T. Rineka cipta, Jakarta.

Mertokusumo, Sudikno. 1984. Bunga Rampai Ilmu Hukum. Penerbit Liberty, Yogyakarta.

Soekanto, Soerjono. 1982. Kesadaran Hukum dan Kepatuhan Hukum, Edisi Pertama, CV. Rajawali, Jakarta. ... 1985. Efektivikasi Hukum dan Peranan Sanksi. Penerbit CV Remaja Karya, Bandung.

............ . 1990. Polisi dan Lalu lintas (Analisis menurut Sosiologi Hukum), Bandar Maju, Bandung.

Taneko, Soleman B. 1993. Pokok-Pokok Studi Hukum Dalam Masyarakat. Penerbit PT Raja Grafindo Persada, Jakarta.

Wignjosoebroto, Soetandjo. 2002. Hukum, Paradigma, Metode dan Dinamika Masalahnya. Penerbit ELSAM, Jakarta.

www.kompascomunity.com/indeks.php?fuseactionhome.detail\&id. Diakses tanggal 21 Juli 2018. 